\title{
THE EFFECT OF AUTHENTIC MATERIALS ON STUDENTS' LISTENING PROCEDURAL TEXT ABILITY OF THE 2018/2019 NINTH YEAR STUDENTS AT SMP SWASTA DEWANTARA PUTRA SEBERTUNG
}

\author{
Ummi Umara, M.Hum ${ }^{1}$, Renita Sari . ${ }^{2}$
}

\begin{abstract}
The study deals with an experimental research design which seeks for the effect of authentic materials on students' listening procedural text ability. The problems that had been identified by the writer are including the students have many difficulties in learning English, such as understanding the listening lesson especially for procedure text, they are not able to achieve the standard valuing scores in listening lesson, lack of vocabulary of the students makes them feel so confused to understand the whole contents of the text, the learning materials are not in accordance with natural conditions and environment of the students, the instructional media cannot be used to motivate the students to improve their English listening, and the strategy implemented in teaching procedure text by the teacher is undrilled to subject later. 70 students at the ninth year students at SMP Swasta Dewantara Putra Sebertung in academic year of 2018/2019 are taken as the subject of the study. Listening test is used to obtain the data on the variable. The final data then is analyzed by using technique of $t$-test analysis. The result shows that coefficient of $t_{\text {counted }}$ (2.15) was greater than the $t_{\text {table }}$ coefficient (1.68595). This means that there is the effect of authentic materials on students' listening procedural text ability of the 2018/2019 ninth year students at SMP Swasta Dewantara Putra Sebertung. Therefore, the hypothesis of the study is accepted.
\end{abstract}

Keywords: Authentic Materials, Procedure Text, Listening Ability

\section{INTRODUCTION}

English, as one of the most used languages in the world, is very important to be learnt because it is a global language, a means for international communication. It has been also used in many different fields including economics, politics, technology and industry. A great number of scientific books are written in English. Gradol's study (as cited by Jarvis) states that in the year 2000 there were about a billion of English learners - but a decade later, the 
numbers will have doubled in 2010. As a fact, in Indonesia, English has been officially adopted as a foreign language.

Education has a strategic role in the development of nation. The quality of human resource of nation can be improved by education. Thus education has to be able to ensure the equality in opportunity to get education, the improvement of education quality, the improvement of education relevance, and the improvement of efficiency of education management. And then need professional teacher to process teaching-learning and good quality on study.

In education, teaching English can be classified into four skills, namely listening, speaking, reading and writing. Listening is an astoundingly complex cognitive process. All of the language skills is supporting each others, listening for detail, speaking to make a speech, reading for general understanding, and writing to make a note. From those skills, the curriculum for English teaching is designed. Listening is a complex problem solving skill and it is more than just perception of the sounds.

When conducting teaching in the class, the writer still finds the students having got problems in learning English especially in listening to English text. Based on the writer's experience when conducting Integrated Field Teaching Program (PPLI), the writer has found several factors disadvantaging students in listening to a procedure text, namely the instructional media cannot be used to motivate the students to improve their English listening, lack of vocabulary of the students that makes them feel so confused to understand the whole contents of the text, and the students cannot understand the text which is difficult to listen. Another fact states that the students' overall score is still low; in this case their scores are under the criteria of minimal completeness (KKM) namely 65. The students mostly make scoring in interval $50-65$ which it means that there are $28.6 \%$ of all the students who have not been almost mastering the procedure text in case of listening skill, the score interval is based on the standard of evaluation. Learning materials are not in accordance with natural conditions and environment of the students, where they live around people who do not mostly use English as their foreign language instead of Indonesian as their first language so that students 
are not easy to understand and have lack of vocabularies. To confront the problem, the teacher must provide the students with appropriate teaching methods. Therefore, applying the appropriate teaching methods plays an important role in the teaching-learning process, including in the teaching of listening to procedure text.

According to the problem, besides the students have many difficulties in learning English listening lesson for procedure text and they are not able to achieve the standard valuing scores (KKM) in listening lesson which both problems are proved by the score result of three sampling students who have got the listening test scores below the standard valuing scores (KKM) i.e. Ratih who has got 62, Andre who has also got 62, and Kesya who has got 63 in the test. The teacher has to be able to use a variety of teaching strategies and make rational decisions about when each of the teaching strategies is likely to be most effective because the strategy implemented in teaching procedure text by the teacher is previously undrilled to subject later, moreover the instructional media cannot be used to motivate the students to improve their English listening because it seems too conventional and traditional thus the students hardly to be stimulated in learning English listening to procedure text just if the teacher uses lots of imitative things to work at the class. The teacher cannot hope to improve her teaching if the teacher is not prepared to experiment with the strategies, and to learn from her experience. Nowadays, the teaching English in Indonesia is based on a text approach. It means that what a teacher should teach is a text. A text is not limited to something written down. A text can be a film, an artifact, anything in a language and culture that conveys meaning. The important thing to start with is to narrow down the meaning of 'authentic materials'. Ability to express meaning in a simple short monologue using a variety of spoken language accurately, fluently and acceptably in order to interact within the context of everyday life in a given context form of procedure is one of the basic competences that must be mastered by students. In teaching a procedure text, the students are asked to read and translate the text. 
Furthermore, the students are asked to do the exercise based on the procedure text. During the process of learning, the students seem very passive and complained, and feel insecure. The students have great difficulty in doing these duties. Obviously learning is not very effective or in other words, learning is unsuccessful. As a teacher, someone must be able to find a teaching technique that fits to the situation and condition of the classroom. There is very important reason why the teacher should be able to understand meaning. Students who are good in understanding meaning will be easier to do examinations than those who are not incapable in understanding meaning.

The use of authentic materials in classroom is what many teachers involved in language teaching. It is persuasive voices insisting that the English presented in the classroom should be authentic, not produced for instructional purposes. Generally, what this means is materials which involve language naturally occurring contexts of use, or rather those selected contexts where standard English is the norm: real newspaper reports, for example, real magazine articles, real advertisements, cooking recipes, horoscopes, etc. Most of the teachers throughout the world agree that authentic texts or materials are beneficial to the language learning process, but what is less agreed is when authentic materials should be introduced and how they should be used in classroom.

From the explanation above, the writer will conduct a research with the title “The Effect of Authentic Materials on Students' Listening Procedural Text Ability of the 2018/2019 Ninth Year Students at SMP Swasta Dewantara Putra Sebertung."

\section{DISCUSSION}

\section{a. Listening}

As defined by Hornby, listening is a complex problem solving skill and it is more than just perception of the sounds. Listening includes comprehension of meaning words, phrases, clauses, sentences, and connected discourse. ${ }^{1}$

\footnotetext{
${ }^{1}$ AS. Hornby. Oxford Advanced Learner's Dictionary of Current English (5 $5^{\text {th }}$ Edition). (Oxford: Oxford University Press, 2010), p.345.
} 
Furthermore according to Nunan, listening is one of the fundamental language skills. ${ }^{2}$

\section{b. Procedure Text}

A procedure text is a type of text which tells the reader how to make or do something ${ }^{3}$. It gives short, clear instructions to enable the reader to achieve a goal. A procedure text explains how to do something through a series of steps ${ }^{4}$. The main purpose of a procedure text is to direct, inform and explain. Procedures must serve a purpose and must be appropriate for an audience such as a child or adult. Procedures may be spoken, written or visual and can take place face to face, in a written form or in the media.

\section{c. Listening Procedure Text}

One of important notions in the teaching of listening is examining the notion of genre, how it relates to teaching listening. The genre that is being taught in the eighth graders of Junior High School is procedure text based on the recent curriculum, namely 2013 curriculum. Procedure text is a text that gives instructions to do something. Another condition of procedure text is to explain how something works through a sequence of actions or steps and also deals with human behavior. Within education, the term children are used for learners between the ages of about 2 to about 14 .

\section{d. Teaching Media}

The media in the classroom wisely expected to bring the messages or information from the resource (teacher) through several channels (visual, Audio-visual, sense and performance) to the receiver (students or a group of students). In this case, the role of the teachers are passive, they help only when they needed, and give feedback on learners' progress based on the test results.

\footnotetext{
${ }^{2}$ David Nunan. Designing Task for the Communicative Classroom. (Cambridge: University Press, 2008), p.45.

${ }^{3}$ June Keir, Informative Texts, (Greenwood: Ready-Ed Publications, 2009), page 8.

${ }^{4}$ John Barwich, Targeting Text, (New South Wales: Blake Education, 2009), page 34.
} 


\section{e. Authentic Materials}

The definitions of authentic materials are slightly different in literature. What is common in these definitions is 'exposure to real language and its use in its own community'. Instead, they were created with some real-life goal for, generally, native speakers. They include both spoken and written language samples. Authentic material is also defined as 'appropriate' and 'quality' in terms of goals, objectives, learner needs and interest and 'natural' in terms of real life and meaningful communication. ${ }^{5}$ And there is also defined authentic texts as materials which are designed for native speakers; they are real text; designed not for language students, but for the speakers of the language. He refers to authentic texts as texts that are not written for language teaching purposes.

\section{f. Authenticity}

According to Rost, authenticity is one of the terms which researchers talk about questionably. ${ }^{6}$ Defining 'authenticity' is a vital element for both materials designers and language teachers, who are willing to employ authenticity in language teaching in EFL classrooms.

\section{RESEARCH METHOD}

This study was conducted by applying a research or study named experimental research design. There were two groups, namely experimental group and control group. The experimental group was the group which received the treatment by applying the strategy of authentic materials at the class while the control group did not. It means that this study intends to find out whether there is the effect of authentic materials on students' listening procedural text ability of the 2018/2019 ninth year students at SMP Swasta Dewantara Putra Sebertung. This research was conducted at SMP Swasta Dewantara Putra Sebertung, Jalan

\footnotetext{
${ }^{5}$ W. Guariento. Text and Task Authenticity in the EFL Classroom. (ELT Journal 55, 2001), page 34

${ }^{6}$ M. Rost. Teaching and Researching Listening. (London: Longman, 2002).
} 
Jamin Ginting Kecamatan Bohorok Kabupaten Langkat. The reason for choosing this school was due to the terms of accessibility and collecting the data. And the time of the research was in August 2018.

The population in this study took the ninth year students at SMP Swasta Dewantara Putra Sebertung. The total population was 40 students in two classes. Each of class consisted of 20 students. According to Ary, it is usually easiest to identify the population - those people about whom you wish to learn something. All of the populations was as samples. The research focused on the class which was divided into two classes. One class was taught by applying the strategy of authentic materials which was called as experimental group, while the other class was not taught by applying the strategy of authentic materials which was called as control group.

In conducting this research, the instrument is used to collect the data namely listening test to collect the data by applying list of blank words with its real (authentic) materials according to the topic. The writer gave 10 procedure listening tests where each correct answer was given 10 scores and 0 for the wrong answer, so the maximum score was 100 . This test was taken from the student's text book, giving an explanation to the student and asking them to answer the question around the procedure text. After the data has been analyzed, the writer found the sum of the score in distribution that was used to calculate the mean. The mean was the arithmetical average that was obtained by adding the sum offset score and dividing to the number of students.

\section{THE DATA AND DATA ANALYSIS}

In this study, the writer used the data which was gathered from the ninth year students of the 2018/2019 at SMP Swasta Dewantara Putra Sebertung. In addition, a clear description about the students' basic ability (Pre-test) in listening procedural text ability for experimental group that was taught by applying the authentic materials was explained as the writer has calculated the whole scores (1360) and then divided the summary with total sample i.e. 20 students then the mean worth as 68. Thus it meant that students in this experimental group 
approximately could answer the questions in standard level. A clear description about the students' basic ability (Pre-test) in listening procedural text ability for control group that was taught by applying no strategy was explained as the writer has calculated the whole scores (1020) and then divided the summary with total sample i.e. 20 students then the mean worth as 51 . Thus it meant that students in this control group approximately could answer the questions in low level.

To test the validity and reliability of the instruments, the writer has got that coefficient of $t_{\text {counted }}$ was 4.48 . Then to find out the validity of the instrument, the coefficient of $t_{\text {counted }}$ was consulted to the $t_{\text {table }}$ coefficient with significance level $(\alpha)=0.05$ and degree of freedom $(d f)=18$. So it could be seen that coefficient of $t_{\text {counted }}(4.48)$ was greater than the $t_{\text {table }}$ coefficient (1.73406). It means that the instrument of testing was valid. Then the writer also has got that coefficient of reliability was 0.784 . Then to interpret the reliability of the instrument, the coefficient of reliability was consulted to the $r_{\text {table }}$ coefficient with significance level $(\alpha)=0.05$ and degree of freedom $(d f)=18$. So it could be seen that coefficient of reliability $(0.84)$ was greater than the $r_{\text {table }}$ coefficient $(0.3783)$. It means that the instrument of testing was reliable.

To analyze the data, all scores of tests were needed. It was got that coefficient of $t_{\text {counted }}$ was 2.15. Then to find out the effect of the variable $\mathrm{X}$ on $\mathrm{Y}$, the coefficient of $t_{\text {counted }}$ was consulted to the $t_{\text {table }}$ coefficient with significance level $(\alpha)=0.05$ and degree of freedom $(d f)=38$. So it could be seen that coefficient of $t_{\text {counted }}(2.15)$ was greater than the $t_{\text {table }}$ coefficient (1.68595). This information indicated the hypothesis of the study was accepted that there is any effect of authentic materials on students' listening procedural text ability of the 2018/2019 ninth year students at SMP Swasta Dewantara Putra Sebertung.

\section{CONCLUSION AND SUGGESTIONS}

\section{a. Conclusion}

The main objective of this study is to determine whether the authentic materials significantly affect on the students' listening procedural text ability. The problems that had been identified by the writer are including the 
students have many difficulties in learning English, such as understanding the listening lesson especially for procedure text, they are not able to achieve the standard valuing scores in listening lesson, lack of vocabulary of the students makes them feel so confused to understand the whole contents of the text, the learning materials are not in accordance with natural conditions and environment of the students, the instructional media cannot be used to motivate the students to improve their English listening, and the strategy implemented in teaching procedure text by the teacher is undrilled to subject later. From the result of this study the writer concludes that there is a significant effect of authentic materials on the students' listening procedural text ability of the 2018/2019 eleventh year students at SMP Swasta Dewantara Putra Sebertung.

\section{b. Suggestions}

From the conclusion stated above, the writer would like to offer suggestions dealing with the result of this study. The suggestions are:

1. Understanding the strategy of authentic materials brings an important role in achieving language skills, therefore the students should improve their ability in listening to any procedural texts.

2. The students also should do more audio exercises in order to enhance their ability in listening to any procedural texts while learning by authentic materials and to give motivation for the students to improve their intensity in listening to any procedural texts.

3. The teacher will be to give the students the possible ways to overcome the problem in listening to any procedural texts.

4. The researchers who want to be observing other problem in teaching English, especially ability in listening to any procedural texts will have some beneficial inputs. 


\section{REFERENCES}

Anderson, Mark and Anderson, Kathy. Text Type in English. South Yarra: Macmillan, 2007.

Alexander, J.G., Baldwin, M.S., \& McDaniel, G. (2000, July). Authentic Assessment of Problem-Based Learning [Electronic Version]. Journal of Alabama Academy of Science. 71 (3), 89.

Anderson, Mark and Anderson, Kathy. Text Type in English, South Yarra: Macmillan, 2007.

Apsari, Yanuarti, The Use of Authentic Materials in Teaching Reading Comprehension (A Thesis Journal). Bandung: STKIP Siliwangi, 2014.

Ary, Donald; Jacobs, Lucy Cheser; and Sorensen, Chris, Introduction to Research in Education. Canada: Wadsworth, 2010.

Azri, Rashid Hamed Al, Al -Rashdi, Majid Hilal, The Effect of Using Authentic Materials in Teaching (International Journal of Scientific \& Technology Research), Volume 3, Issue 10, October 2014.

Bacon, S.M. \& Finnemann, M. D. A Study of the Attitudes, Motives, and Strategies of University Foreign Students (1990), Modern Language Journal.

Barwich, John. Targeting Text, New South Wales: Blake Education, 2009.

Bosworth, K., \& Hamilton, S. Collaborative Learning: Underlying Process and Effective Techniques. San Francisco, CA: Jossey-Bass Publishing, 2004. 